The Philosophical Journal of Conflict and Violence

Vol. II, Issue 2/2018

(C) The Authors 2018

Available online at http://trivent-publishing.eu/

\title{
Mixed Martial Arts: Civilizing or Decivilizing Process? A Bibliometric Analysis
}

\author{
Robin Delory, ${ }^{1}$ Pascal Roland, ${ }^{2}$ Olivier Sirost ${ }^{3}$ \\ ${ }^{1}$ University of Normandie, UNIROUEN, CETAPS, Rouen, France, robin.delory@etu.univ-rouen.fr \\ ${ }^{2}$ University of Normandie, UNIROUEN, CETAPS, Rouen, France, pascal.roland@univ-rouen.fr \\ ${ }^{3}$ University of Normandie, UNIROUEN, CETAPS, Rouen, France, olivier.sirost@univ-rouen.fr
}

\begin{abstract}
Within the sporting landscape much has changed from the proliferation and integration of new technologies, for example, the practice of mixed martial arts (MMA) has developed on the fringes of modern sport. It combines several martial arts, is practised in a cage, and allows ground strikes. $M M A$ is presented here within a framework inspired by Norbert Elias's theory of civilizing of aggressive impulses through sport. We reviewed more than 20 years of literature, with 785 international references and a triple analysis of the discipline, those being physical violence, symbolism, the play impulse.
\end{abstract}

Keywords: Norbert Elias; Bibliometric Analysis; Decivilizing Process; Mixed Martial Arts; Quest for excitement; Violence.

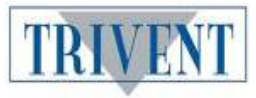

The PJCV Journal is published by Trivent Publishing.

This is an Open Access article distributed in accordance with the Creative Commons Attribution Non Commercial (CC-BY-NC-ND 4.0) license, which permits others to copy or share the article, provided original work is properly cited and that this is not done for commercial purposes. Users may not remix, transform, or build upon the material and may not distribute the modified material (http:/ / creativecommons.org/ licenses/by-nc/4.0/) 


\title{
Mixed Martial Arts: Civilizing or Decivilizing Process? A Bibliometric Analysis
}

\author{
Robin Delory, Pascal Roland, Olivier Sirost \\ University of Normandie, UNIROUEN, CETAPS, Rouen, France \\ robin.delory@etu.univ-rouen.fr, pascal.roland@univ-rouen.fr, olivier.sirost@univ-rouen.fr
}

\begin{abstract}
Within the sporting landscape much has changed from the proliferation and integration of new technologies, for example, the practice of mixed martial arts $(M M A)$ has developed on the fringes of modern sport. It combines several martial arts, is practised in a cage, and allows ground strikes. $M M A$ is presented bere within a framework inspired by Norbert Elias's theory of civilizing of aggressive impulses through sport. We reviewed more than 20 years of literature, with 785 international references and a triple analysis of the discipline, those being physical violence, symbolism, the play impulse.
\end{abstract}

Keywords: Norbert Elias; Bibliometric Analysis; Decivilizing Process; Mixed Martial Arts; Quest for excitement; Violence.

\section{Introduction}

Among the many processes for transforming competitive sport, the civilization of violence has again come to the foreground, notably in sociological debates. ${ }^{1}$ The media tends to focus on the most striking issues, like uncivil behaviours in soccer or lawsuits for injury in professional American football. Meanwhile, the study of more banal accidents in noninstitutional sports, e.g. hiking and skiing, has risen exponentially. In this vast landscape, mixed martial arts (MMA) has found a place on the international scene in the last twenty years. It first appeared as a complete transgression of human dignity, recalling the blood thirst of the early gladiator games. Yet, MMA practiced at a high level quickly has become recognized as a genuine sport and today seems less dangerous and traumatic than even boxing and some other combat sports. However, amateurs have now taken it up in many countries, and this is a cause for worry because the combatants and referees may be inadequately trained, and as well, clandestine combats are often organized. MMA has therefore drawn questions from the fields of education, medicine, and ethics. Notably, it poses the problem of a contradiction in logic, first expressed by Norbert Elias:

...one of the essential problems of sport; namely, how to reconcile two contradictory functions: one, the pleasing relaxation of control over human feelings, the manifestation of "a pleasant excitement", and the other, the

\footnotetext{
${ }^{1}$ See Dominic Malcolm, Louise Mansfield, “The Quest for Exciting Knowledge: Developments in Figurational Sociological Research on Sport and Leisure," Política y Sociedad 50 (2013): 397-419; Richard Giulianotti, Sport and Modern Social Theorists (New York: Palgrave Macmillan, 2004).
} 
maintenance of a set of codifications in order to keep control of the emotions pleasantly out of control. ${ }^{2}$

Mixed martial arts, which encompasses all combat disciplines and is practiced in a cage where even striking an opponent on the ground is authorized, was up until recently considered illegitimate and illegal for competition on French territory. Yet it has been widely covered by the media, especially digital media, as it has for function the storytelling narrative, the mythologizing of society. ${ }^{3}$ It shares deep homologies with electronic sports, another phenomenon which is undergoing radical development. A significant question today is whether MMA represents the ultimate endpoint in controlling aggressive impulses or, on the contrary, a proof of the need to challenge Elias's thesis, which, as H.P. Duerr points out ${ }^{4}$ is supported by a colonial ideology of civilized humanity. Is it not possible that what is occurring is a playful relocation of sports games rather than a civilized globalization of sport, just as Stephen Mennell argued about the emotions generated by sport? ${ }^{5}$ Along similar lines, D. Malcolm ${ }^{6}$ and L. Mansfield ${ }^{7}$ have shown the primacy of singular bodily experience in the formalization of knowledge. From these perspectives, MMA might be in the forefront of a decivilizing process characterizing the collapse of the dogmas of modernity. In order to better specify this question, we conducted an international bibliometric analysis of the MMA phenomenon, which relies in particular on illegal and illegitimate practice, and also focused on the research literature in the social sciences wherein the researcher investigates through their bodily experience. In doing so, we make use of the main indicators described by Norbert Elias concerning the civilizing process via physical brutality, discipline in sport, and the aggressive impulses expressed in the sports game.

These indicators are a way of objectifying Elias's theses in the study of combat sports. In Boxing \& Duelling, Norbert Elias insisted, for example, on the folkloric and unsavoury nature of savate (a French fighting discipline in which feet and fists are used) as opposed to the sporting and noble nature of boxing. The civilizing process should thus be sought by exploring not only standards and taboos, but also the expression of emotions, including "the barrier of strong negative feelings, of revulsion and disgust." "These inversions are objectified via the categories we have chosen for our systematic analysis of the scientific literature on MMA. Elias first insists on the use of the body as a weapon capable of attacking others and inflicting injury on enemies. This physical violence is then dealt with symbolically via issues of legitimacy and class power. Last, the sportivization of boxing and savate moves the issue of violence over to the practitioner's instinct, for which exploring the technical possibilities and authorized gestures becomes the rule. By following this Eliasian approach, we analyse the international literature on MMA according to three indicators: physical violence (injuries

\footnotetext{
${ }^{2}$ Norbert Élias, Eric Dunning, Sport et civilisation : La violence maitrisée (Paris : Fayard, 1994). Authors' translation. Our emphasis.

${ }^{3}$ Roland Barthes, Mythologies (Paris: Seuil, 1957).

${ }^{4}$ Hans Peter Duerr, Nudite Et Pudeur: Le Mythe Du Processus De Civilisation (Paris: Maison Des Sciences De L'homme, 1998).

${ }^{5}$ Stephen Mennell, "The Contribution of Eric Dunning to the Sociology of Sport: The Foundations," Sport in Society: Cultures, Commerce, Media, Politics 9 (2006): 514-532.

${ }^{6}$ Dominic Malcolm, "Sport Medicine, Injured Athletes and Norbert Elias's Sociology of Knowledge," Sociology of Sport Journal 28 (2011): 284-302.

7 Louise Mansfield, "Reconsidering feminisms and the work of Norbert Elias for understanding gender, sport and sport-related activities," European Physical Education Review 14 (2008): 93-121.

8 Jan Haut, Dolan Paddy, Dieter Reicher, Raul Sanchez Garcia, Excitement Processes. Norbert Elias's unpublished works on sport, leisure, body, culture (Wiesbaden: Springer VS, 2018). Our emphasis.
} 
and bodily harm), symbolic violence (the power of images and legitimacy), and the playful impulse.

\section{State of the Art of MMA: Methodology}

MMA became formalized in 1993, at the first Ultimate Fighting Championship (UFC). The only regulation of "cage fighting" at that time was the prohibition of biting and tearing at the opponent's eyes. There were no weight categories or time limits, and the fights ended by giving up or knockout. The UFC was developing on the side-lines of the sports circuits, mainly in the emerging and poorly controlled market of pay-per-view (PPV). This led to the desportivization of MMA because violence was increasing in a context of illusory regulation. ${ }^{9}$ The antithetical tension ${ }^{10}$ of the MMA spectacles reflected the public's excitement while watching social norms be transgressed, with TV viewers exerting influence over practitioners and direct spectators. In recent years, MMA has sought to free itself from the violent image of the earliest events, especially since 2003 with the introduction of the "Unified Rules of Mixed Martial Arts". ${ }^{11}$ It is nevertheless still prohibited in some countries, like France, especially because the intention to injure is accepted, hitting opponents on the ground is authorized, and cage fighting is seen, in general, as particularly violent. MMA has been slow to undergo sportivization because of its commercial character, its detachment from any sports institution, the controversies around its legitimacy and the divergent and competing aspirations of the sport.

In this article, we contextualize the main themes that emerge from the MMA bibliography, with a focus on three categories, those being: (1) physical violence, around trauma, physiology, and the researcher's body; (2) symbolic violence, around spectacle, images, gender, and the legal/legitimate debate about MMA; and (3) and the playful impulse, around its historicity, techniques, sportivization and various applications.

\section{A. Epistemology of MMA: Fields of Research and Historicity of Publications}

For our research we searched three databases (Cairn, Perseus and SUDOC), two research portals (Google Scholar, ResearchGate), and four international publishers (Sage, Taylor \& Francis, Elsevier, Routledge) since February 2018 using the following keywords: "arts martiaux mixtes," "mixed martial arts," "MMA," and "sport". Of all the results, only research articles on mixed martial arts were selected. Also, we did not limit the search to the French and Anglo-American literature. The initial search yielded the following results: Cairn: 183 references; Perseus: 217,676; SUDOC: 1087; Google Scholar: 2790; ResearchGate: 466; Sage: 1815; Taylor \& Francis: 5355; Elsevier: 3770; and Routledge: 1. After analysis, 5/183 results from Cairn, 0/217,676 from Perseus, and 22/1087 from SUDOC were retained. We retained 388/2790 from Google Scholar and 267/466 from ResearchGate. We also retained 41/1815 from Sage, 37/5355 from Taylor \& Francis, 22/3770 from Elsevier, and 1/1 from Routledge.

\footnotetext{
${ }^{9}$ Maarten van Bottenburg, Johan Heilbron, "Genèse et Dynamique des "combats ultimes"," Actes de la Recherche en Sciences Sociales 179 (2009) : 32-45.

${ }^{10}$ Randall Collins, Interaction Ritual Chains (Princeton: Princeton University Press, 2004).

${ }^{11}$ Matthieu Delalandre, Cécile Collinet, "Le mixed martial arts et les ambigüités de sa sportification en France," Loisir et Société 35 (2012): 293-316.
} 


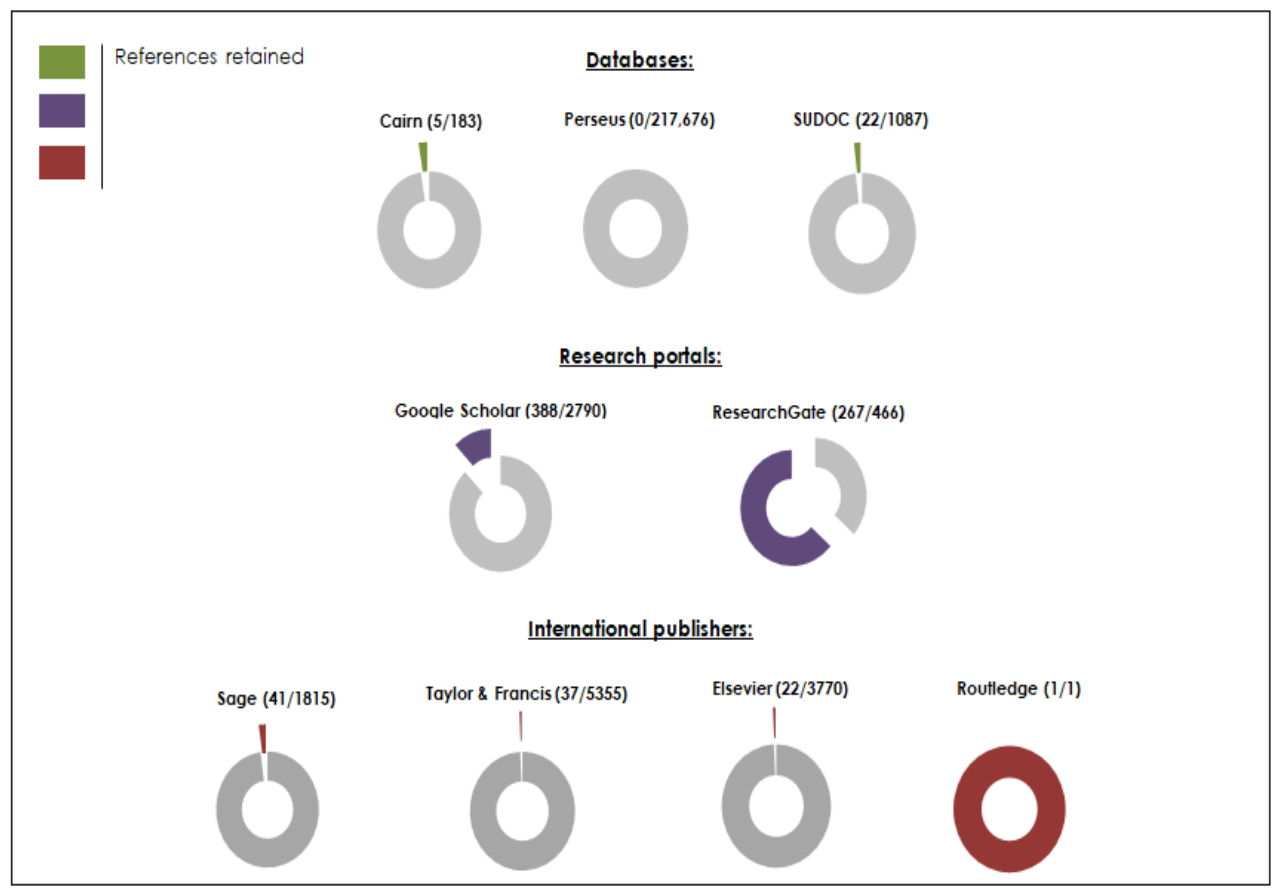

Fig. 1. Selected research articles

Of the 242,047 results, we selected 783 references corresponding to a variety of media (research articles, books, theses, dissertations, conferences, communications, and posters). Two additional references were retrieved: one from the Google search engine, the other manually, for a total of 785 references. As some of the studies were part of multi-, inter-, or transdisciplinary projects, 16 research fields were represented for a total of 893 MMArelated correspondences. 


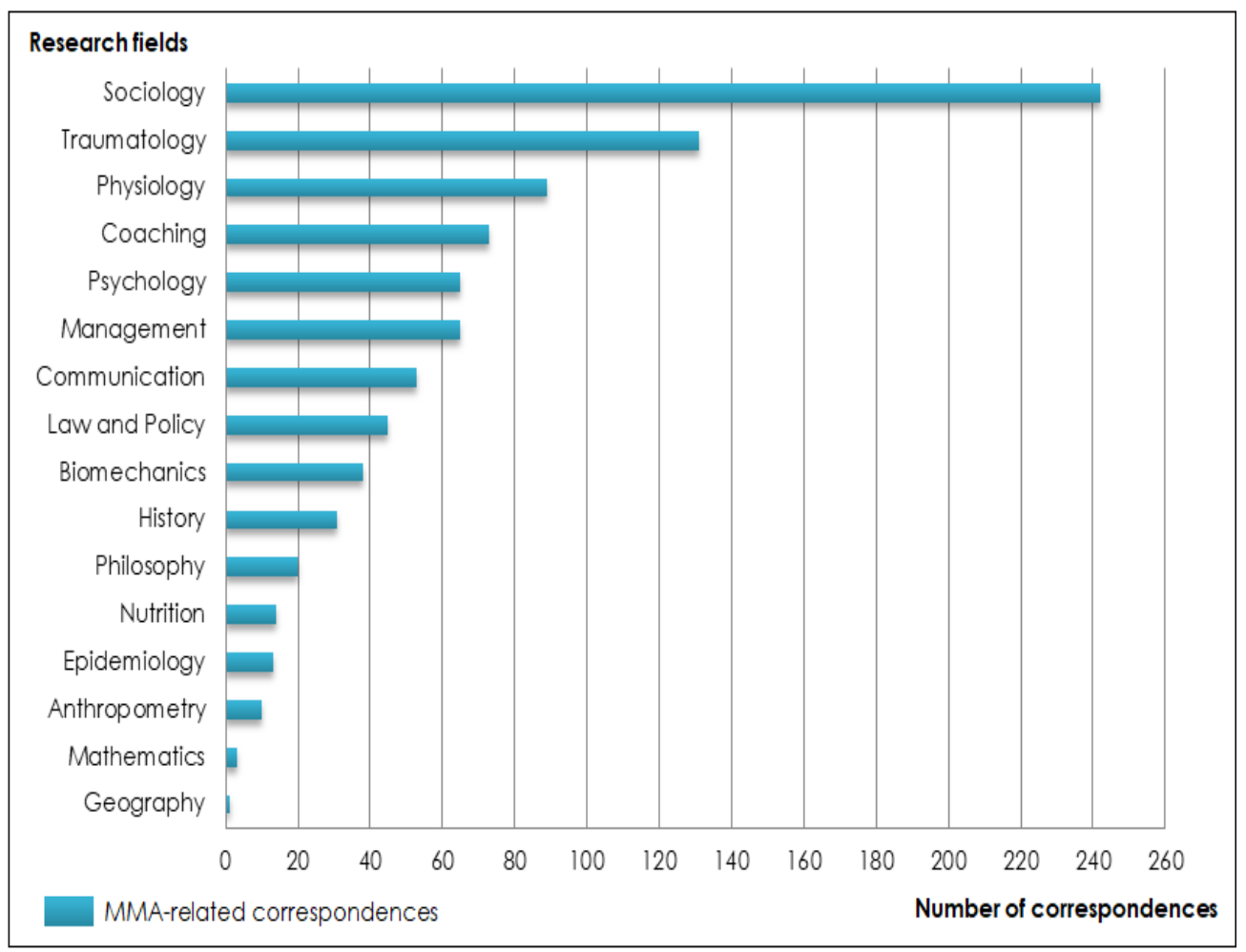

Fig. 2. Correspondences to MMA and research fields

The different forms of MMA were investigated in these various fields, mainly in the 2000s, with the exception of "free fighting" in the 1990s. Although sociology, traumatology, physiology and coaching are most represented, bibliometric analysis reveals a relevant and consistent literature on MMA in the other disciplines.

The examination of the MMA bibliography ending in February 2018 and its graphical representation does not show lower growth in scientific production in this last year, contrary to what the curves suggest. The first few months, in fact, seem to indicate a steady increase in scientific interest in MMA. Unpublished references and those without information on their historicity $(n=8)$ have not been included in this chart. A total of 884 correspondences, or 777 of the 785 references, are thus represented. 


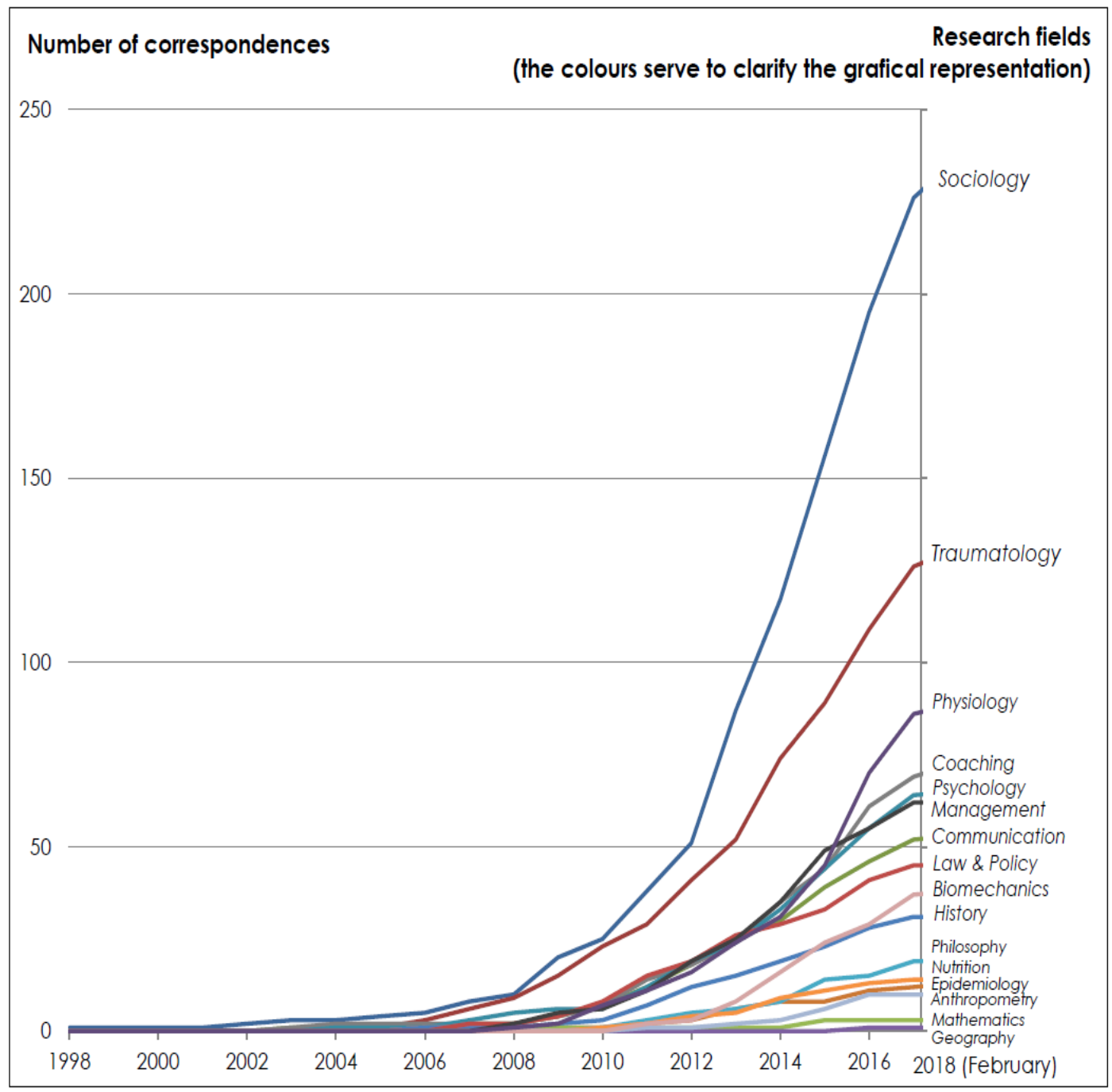

Fig. 3. Historicity of MMA publications

\section{B. Selection of articles and constitution of the reference base}

The table is not exhaustive for reasons of space, but it nevertheless provides a glimpse into the most frequently cited research articles associated with MMA. The authors selected in the table below are the most cited with the most publications on MMA, as indicated by search engines like PubMed or those of publishing houses. In addition, mapping brings to the fore the leading authors and articles that we analyse further on. 


\begin{tabular}{|c|c|}
\hline Research field & Leading articles \\
\hline Sociology & $\begin{array}{c}\text { M van Bottenburg (2006); G Downey (2007); R Sánchez García } \\
\text { (2010); } \\
\text { K Green (201 1); DC Spencer (2009, 2012, 2013) }\end{array}$ \\
\hline Traumatology & $\begin{array}{c}\text { RP Lystad (2014); F Hernandez (2015) } \\
\text { T Kochhar (2005); GJ Buse (2006); GH Bledsoe (2006); Ngai KM }\end{array}$ \\
\hline Physiology & JA Amtmann (2008); SM McGill (2010); S Lenetsky (2012); P Alm \\
\hline Coaching & JA Amtmann (2003, 2004); P La Bounty (2011) \\
\hline Management & K Seungmo (2008); S Kim (2009); DPS Andrew (2009) \\
\hline Psychology & CA Vaccaro (201 1); J Haydicky (2012); S lermakov (2016) \\
\hline Communication & N Cheever (2009); CH Lim (2010); EL Frederick (2012); NA Brown \\
(2013)
\end{tabular}

Fig. 4. Research fields and leading articles associated with MMA

From this compilation of the 785 selected references, we then carried out a targeted search for articles relating to various research themes: the researcher's body in ethnographic studies of MMA (63 references or $8 \%$ ), with 26 of them, or $3.3 \%$, specific to sensory ethnography; traumatic and physiological impacts of MMA (respectively, 131 and 89, or $16.7 \%$ and $11.3 \%$ ); MMA as spectacle and image (74 or $9.4 \%$ ) including 4 , or $0.5 \%$, specific to MMA and video games; gender studies in MMA (101 or 12.9\%); and the sportivization of MMA (232 or $29.5 \%)$, with $61(7.8 \%)$ specific to its technical and educational dimensions and $127(16.2 \%)$ specific to the legality/legitimacy debate related to this discipline. 


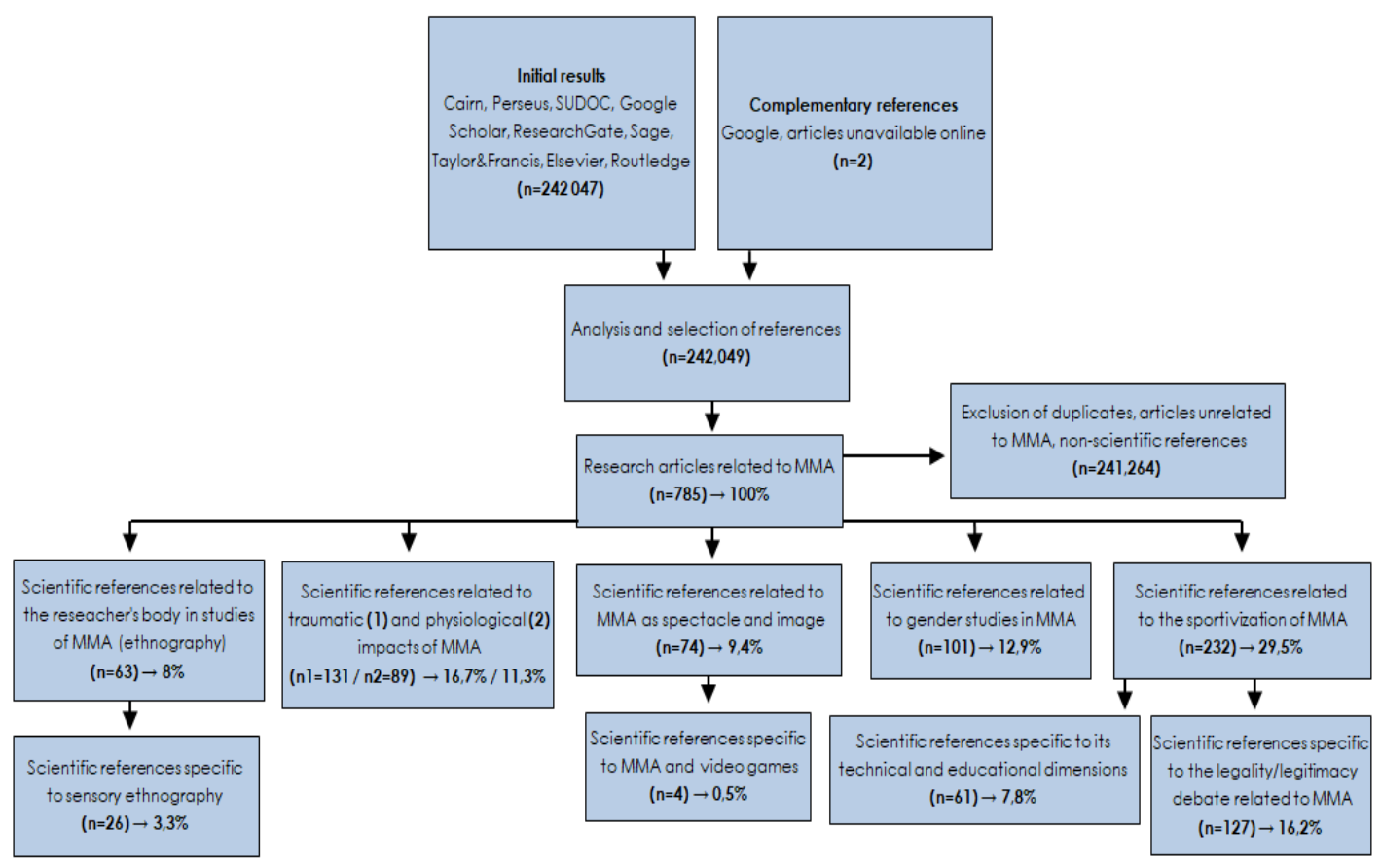

Fig. 5. Thematic analysis of the MMA bibliography

\section{Discussion of Norbert Elias's theses}

A thematic presentation of the articles on MMA shows the relevance of mobilizing and discussing Norbert Elias's theses. The key words, such as legality, legitimacy, traumatism, injury, corporal techniques, symbols, images, spectacle, play, and sensoriality, are all at the heart of the civilizing and sportivization processes. Although Elias's work is regularly consulted in the social sciences, it has not escaped criticism, with some critics going so far as to even question the theory of the civilizing process. At the root of this controversy is H.P. Duerr's refutation, as this author particularly denounces the assumption of the inherent superiority of the "civilized" Western cultures as opposed to the "non-Western" cultures. In his opinion, this further legitimizes the classification and categorization of groups and behaviours that can then be imposed on peoples, a notable example being the colonialist ideologies. ${ }^{12}$ Yet Elias himself opposes this vision, as well. ${ }^{13}$ Duerr's material and methods may have caused disagreement, but his work has nevertheless opened reflection on "a theory sometimes too quickly accepted" in which "the unequivocal processes of acculturation, systematically top-down oriented and rather arbitrarily affirmed by Elias, can be challenged by many concrete observations of natural mechanisms." 14

12 See Dominique Linhardt, "Le procès fait au Procès de civilisation. A propos d'une récente controverse allemande autour de la théorie du processus de civilisation de Norbert Elias," Politix 14 (2001): 151-181.

13 See Norbert Elias, Les Allemands, Luttes et pouvoir et développement de l'babitus aux XIXe et XXe siècles. Paris: Seuil, 2017. See also Florence Delmotte, "Une théorie de la civilisation face à " l'effondrement de la civilisation "," Vingtième Siècle. Revue d'bistoire 106 (2010): 54-70.

14 Etienne Anheim, Benoît Grévin, "Le procès du "procès de civilisation" ? Nudité et pudeur selon H.

P. Duerr," Revue d'histoire moderne \& contemporaine 48 (2001): 160-181. Authors' translation. 
Elias's theory of the civilizing process assumes that civilization moves upward, without origin or end. This process can be conceptualized, and all societies can be classed from the "least" to the "most" civilized. How then should we think about the dramatic events that marked the twentieth century? According to this sociologist, the ruptures and regressions of contemporary civilization stem from long and complex socio-historical configurations and processes. Nazism, for example, developed through the "German habitus." 15 This kind of collapse, distinct from other decivilizing movements, does not break with the civilizing processes, according to Elias. ${ }^{16}$ Instead, it indicates "a decivilizing process in which behaviours appear, again from a formal point of view, as concordant with the requirements of civilization. Formalization, in this case, operates like a veil obscuring true barbarism." 17 In fact, as Elias states, the civilizing process is nonlinear and part of the permanent tension between civilization and de-civilization. ${ }^{18}$

To understand the evolution of the civilizing processes, Cas Wouters assumes that the major trends presented by Elias continued until the end of the nineteenth century. ${ }^{19}$ Through the aristocratization of the bourgeoisie and the gentrification of the nobility, a phase of the formalization of morals and disciplinarianism prompted people to repress their emotions and practise self-control in increasingly automatic ways. For example, external social constraints were thus transformed into habitual self-restraint, which became "second nature" and controlled by consciousness. In the twentieth century, with the gentrification of the working classes and the proletarianization of the bourgeoisie, a habitus of a "third nature" emerged, favouring the controlled expression of emotions. This third nature, more open and tolerant, involved reflection and regulation via awareness of the suppressed emotions, which became more socially acceptable: an informalization.

In this sense, the "permissive society" resulted from a balance between informalization, self-restraint and a high level of civilization. For example, the structuring of a configuration somewhat apart and singular - the beach - revealed an informal space, tolerating modesty and certain sociabilities (which Granger defines as "decivilizing mechanisms" 20 ). This easing of the rules of conduct and freeing from hierarchies of rank - which are characteristic of informalization - assumes that summer relaxation, beyond the formation of a habitus, reveals places of struggle and violence where the definition of legitimate conduct and their regulation are played out.

Hooliganism is another example for analysing the decivilizing process at work. Eric Dunning points out that violence is more likely to erupt in those sports that pit one team against the other. ${ }^{21}$ Football is a good example, its popularity and the social composition of its support base may explain the legitimization of more aggression and violence, with hooligans tending to come from the lower rungs on the social ladder. To enrich this

\footnotetext{
15 Norbert Elias, Les Allemands, Luttes et pouvoir et développement de l'babitus aux XIXe et XXe siècles.

16 See Florence Delmotte, "Une théorie de la civilisation face à " l'effondrement de la civilisation "."

17 Dominique Linhardt, "Le procès fait au Procès de civilisation. A propos d'une récente controverse allemande autour de la théorie du processus de civilisation de Norbert Elias. " : 158.

18 See Norbert Elias, La civilisation des mours (Paris: Calmann-Lévy, 1973) ; Norbert Elias, Les Allemands, Luttes et pouvoir et développement de l'babitus aux XIXe et XXe siècles. See also Florence Delmotte, "Une théorie de la civilisation face à " l'effondrement de la civilisation "." ; Florence Delmotte, "Termes clés de la sociologie de Norbert Elias," Vingtième Siècle. Revue d'bistoire 106 (2010): 29-36.

${ }^{19}$ Cas Wouters, "Comment les processus de civilisation se sont-ils prolongés? De la " seconde nature » à la " troisième nature "," Vingtième Siècle. Revue d'bistoire 106 (2010): 161-175.

${ }^{20}$ Christophe Granger. "Du relâchement des mœurs en régime tempéré. Corps et civilisation dans l'entre-deux-guerres.” Vingtième Siècle. Revue d'histoire 106 (2010): 115-125.

${ }^{21}$ Eric Dunning, "Approche figurationnelle du sport moderne. Réflexions sur le sport, la violence et la civilisation,” Vingtième Siècle. Revue d'bistoire 106 (2010): 177-191.
} 
configurational postulate, he assumes that "fault lines" reveal the connections between hooliganism and social classes. Although they are country-specific, they are also embedded in complex and overlapping interactions of affiliation, examples being intergenerational relations, the relations between East and West Germany, and religious sectarianism in Scotland and Ireland.22 Thus, the tensions in the civilizing process play out differently according to the social affiliations.

In response to the contention of M. van Bottenburg and J. Heilbron that the emergence of MMA is indicative of "desportivization/decivilization," ${ }^{23}$ R. Sánchez García and D. Malcolm draw on the concepts of "informalization" and the "quest for excitement" to argue that the development of MMA does not break with the civilizing process. ${ }^{24}$ Mobilizing the assumptions of Cas Wouters, the authors argue that - through a balance between formalizing tendencies (with behavioural control explicit and imposed from the outside) and informal tendencies (being more implicit and internally driven) - the growth of MMA reveals an informalizing process. Thus, a "strong illusory element that obscures the significant 'self-controlled' practice" explains the alleged increase in MMA-related violence and its emerging form: no-holds-barred (NHB). Through oscillating, nonlinear phases in order to reach a balance in tensions, these ultimate fights have been sportivized, keeping pace with the highly self-regulated habitus of desensitized practitioners always on the lookout for ever more excitement. Meanwhile, the promoters have introduced cosmetic changes to the competitions to hold the interest of spectators, especially to the outsiders; the non-connoisseurs, the uninitiated and/or the poorly informed for whom the interpretation of an apparent "de-control" of the fights would hide their deeply selfcontrolled nature. R. Sánchez García ${ }^{25}$ combines the analyses from his ethnographic study of recreational MMA in Spain with those of C.M. Abramson \& D. Modzelewski26 on middle-class Americans' participation in MMA and then extends these ideas by connecting the concept of informalization with the social recruitment of MMA. Through the development of a working-class habitus (rough and competitive) that has integrated and mixed with a middle-class habitus (recreational and self-developing), the dissemination of recreational and competitive MMA - this last attracting of members from various social classes, including the middle class - indeed reveals an informal trend and redeploys reflection, self-awareness and the self-regulation of emotions to combat.

In response to R. Sánchez García and D. Malcolm's observations ${ }^{27}$ on their analysis of "ultimate fighting," M. van Bottenburg and J. Heilbron bring out some of the subtleties concerning the different phases of its sportivization. ${ }^{28}$ As opposed to Sánchez García and Malcolm, who associated MMA not with an increase in violence but rather with staging and an illusory perception, these two researchers insist that NHB MMA is more violent than any other combat sport emerging in the 1990s, as evidenced by minimal regulation. Instead of sportivization "in the 'civilizing' sense of Norbert Elias and Eric Dunning," they observe the opposite trend, that is the emergence of cage fights as desportivizing. These illegitimate

\footnotetext{
22 Ibid.

${ }^{23}$ Maarten van Bottenburg, Johan Heilbron, "Genèse et Dynamique des "combats ultimes"” : 32-45.

${ }^{24}$ Raul Garcia Sánchez, Dominic Malcolm, "Decivilizing, civilizing or informalizing? The international development of Mixed Martial Arts," International Review for the Sociology of Sport 45 (2010): 39-58.

${ }^{25}$ Raul Garcia Sánchez, "Informalization, ways of engagement and class habitus in the development of MMA," Corps 16 (2018): 393-401.

26 Corey M. Abramson, Darren Modzelewski, "Caged Morality: Moral Worlds, Subculture, and Stratification Among Middle-Class Cage-Fighters,” Qualitative Sociology 34 (2011): 143-175.

${ }^{27}$ Raul Garcia Sánchez, Dominic Malcolm, "Decivilizing, civilizing or informalizing? The international development of Mixed Martial Arts": 39-58.

${ }^{28}$ Maarten van Bottenburg, Johan Heilbron, "Genèse et Dynamique des "combats ultimes"” : 32-45.
} 
and often illegal events, originally produced by commercial companies and the poorly controlled PPV market, then had to be codified to meet stricter regulations: the authors refer to "resportivization." These authors also contend that interpretation via the concepts of informalization and the quest for excitement is also problematic, in that Sánchez García and Malcolm do not systematically differentiate NHB from MMA. NHB (an emerging form of MMA) implies a desportivizing phase, where producing transgressive excitement among viewers as distinct from that of combatants is the central economic goal. The subsequent phase of resportivization - that is, transforming NHB into MMA, which is "more legitimate and sports-like" - aims at regaining access to the PPV market to benefit the new media companies. According to van Bottenburg and Heilbron, more than the idea of the "ascendancy of professionalism over amateurism" and oscillating phases of more or less violent forms of MMA - as assumed by Sánchez García and Malcolm - there should be a distinction between NHB and MMA, formalized in conjunction with entrepreneurial strategies, differentiated in purpose, and corresponding to different social processes: desportivization followed by resportivization.

According to J-F Loudcher and M. Aceti, the development of MMA could be thought of as concordant with Elias's civilizing process rather than a decivilizing process. ${ }^{29}$ The NHB of the 1990s having led to greater regulation, the authors suggest that "the advent of MMA may have been a kind of temporary regression, conceived by the German sociologist as a possibility for his ideas before a certain form of peaceableness in morals prevailed" (our translation). France's persistent prohibition of this sport thus reflects a paternalistic and centralized state authority whose politico-socio-historical dispositions are incompatible and opposed to MMA's autonomous, market-oriented and a-statist functioning. In addition to revealing the economic stakes of this growing sport, its position outside of the French model, which claims the right to regulate and control legitimate violence, thus justifies the challenges and oppositions to this sport. It can also be assumed that the search to weaken the nation-state through economic liberalism is concomitant with decivilizing oscillations.

\section{Results}

The literature on MMA thus reveals how the sociologist's theses have implicitly guided research and the extent to which successive generations of thought have engaged with and extended Elias's intuitions.

\section{A. Physical violence}

\section{- Medical approaches to MMA: an activity causing more trauma than others?}

A considerable portion of literature is devoted to the effects of MMA on the practitioner's body. Of the 89 references focused on physiological impacts, several warn against the risk of infectious transmission ${ }^{30}$ facilitated by the combat environment and close contact, such as "herpes gladiatorum" or "mat herpes." 31 The dangers related to weight cutting are also

\footnotetext{
${ }^{29}$ Jean-François Loudcher, Monica Aceti "MMA, " procès " de civilisation et sportivisation : repenser la théorie éliasienne pour mieux s'en émanciper ?" Corps 16 (2018): 371-381.

30 Simon K. Lee, "Molluscum Contagiosum Infection in Mixed Martial Arts Fighting: Molluscum Gladiatorum," Journal of Cutaneous Medicine and Surgery 17 (2013): 151-152.

31 Marc Meulener Barry L. Smith, "Herpes Gladiatorum With Ocular Involvement in a Mixed Martial Arts Fighter," Cutis 87 (2011): 146-147.
} 
highlighted $^{32}$, as well as doping behaviours that appear to emerge from a social process closely linked to the practice environment, notably peer influence. ${ }^{33}$

In addition, 131 of the 785 references highlight the diversity and severity of practicerelated injuries, including clinical case analyses (20 studies). Due to the technical diversity and the relative freedom from regulation, the MMA practitioner's entire body is subject to traumatic risk of, for example, ligament injury ${ }^{34}$, muscle syndromes ${ }^{35}$, multiple lacerations ${ }^{36}$, dislocation $^{37}$, fracture ${ }^{38}$, rupture of the tympanic membrane ${ }^{39}$ and brain injury. ${ }^{40}$ The reference database contains a set of 24 systematic studies (meta-analyses, recontextualizations of research studies, database analyses, and literature reviews) providing a global and comparative view of MMA practice. Several of these works ${ }^{41}$ reveal significantly higher injury rates among MMA athletes than those in other combat or contact sports like hockey and football. They report numerous cases of facial laceration, fracture and head trauma. While some suggest that the risk of injury to "mixed martial artists" is likely to be less than or the same as that of practitioners of other martial arts and team sports ${ }^{42}$, the authors agree that studies on MMA-related injuries are lacking and mainly come from orthopaedic medicine. The consensus is strong in denouncing the lack of cartographies and complete definitions of MMA-related injuries and infectious transmissions, as this severely hinders efforts to evaluate their rates and severity. This

32 Adam M. Jetton, Marcus M. Lawrence, Marco Meucci, Tracie L. Haines, Scott R. Collier, David M. Morris, Alan C. Utter, "Dehydration and acute weight gain in mixed martial arts fighters before competition." The Journal of Strength \& Conditioning Research 27 (2013): 1322-1326.

${ }^{33}$ Joshua, Murray, Arnout Van de Rijt, John M. Shandra, "Why They Juice: The Role of Social Forces in Performance Enhancing Drug Use by Professional Athletes," Sociological Focus 46 (2013): 281-294.

34 Joseph F. Baker, Brian M. Devitt, Ray Moran, "Anterior cruciate ligament rupture secondary to a "heel hook": a dangerous martial arts technique," Knee Surgery, Sports Traumatology, Artbroscopy 18 (2010): $115-116$.

35 Alexander D. Lee, Alexander Yu, Shayne B. Young, Patrick J. Battaglia, John C. Ho, "Omohyoid Muscle Syndrome in a Mixed Martial Arts Athlete: A Case Report," Sports Health: A Multidisciplinary Approach 7 (2015): 458-462.

36 Nicholas Bastidas, Jamie P. Levine, Frank L. Stile, "The "sweet science" of reducing periorbital lacerations in mixed martial arts," Annals of Plastic Surgery 68 (2012): 43-45.

${ }^{37}$ Kevin Sims, Andreo Spina, "Traumatic anterior shoulder dislocation: a case study of nonoperative management in a mixed martial arts athlete," The Journal of the Canadian Chiropractic Association 53 (2009): 261-271.

38 Nishant Gupta, Komal Sharma, Itisha Bansal, Yogesh Kumar, Daichi Hayashi, "Kickboxing power hour: case report of fifth metatarsal apophysitis (Iselin disease) and its magnetic resonance imaging features," Translational Pediatrics 6 (2017): 98-101.

${ }^{39}$ Jeffrey D. Fields, Douglas B. McKeag, John L. Turner, "Traumatic tympanic membrane rupture in a mixed martial arts competition," Current Sports Medicine Reports 7 (2008): 10-11.

40 Bush \& Myers, "Concussive brain injury in mixed martial arts: Fighter characteristics and bout outcomes," Applied Neuropsychology 16 (2009): 298.

${ }^{41}$ See Bruce Reider, "Battle Scars," The American Journal of Sports Medicine 42 (2014): 1287-1288;, Reidar P. Lystad, Kobi Gregory, Juno Wilson, "The Epidemiology of Injuries in Mixed Martial Arts. A Systematic Review and Meta-analysis," Orthopaedic Journal of Sports Medicine 2 (2014): 1-10. Bryce Nalepa, Amy Alexander, Sarah Schodrof, Charles Bernick, Jamie Pardini, "Fighting to keep a sport safe: toward a structured and sport-specific return to play protocol," The Physician and Sportsmedicine 45 (2017): $145-150$.

${ }^{42}$ See Stacey Howard Bishop, Paul La Bounty, Michael Devlin, "Mixed martial arts: a comprehensive review," Journal of Sport and Human Performance 1 (2013): 28-42; Jon-Atle Larsen, "Kartleggelse av skaderisiko innen kampsporten [Mapping of injury risk in martial arts]." (Master dissertation, University of Tromsø, 2013). 
consensus also reveals the real concerns about the growth of this discipline and the lack of empirical studies of MMA trauma over the long term, especially in the neurosciences.

\section{- The researcher's Body as Evaluator of Violence}

We identified 64 ethnographic works, including 26 sensorial studies mobilizing the body, the senses and sensations. These epistemological constructions suggest a variety of modes of engagement in this field of study. Although the ethnologist necessarily disturbs what they observe ${ }^{43}$, the corollary is that the study environment also has an impact on the researcher.

Dale C. Spencer reported on retaining traces of his sensory ethnography. ${ }^{44}$ By using his body as an "instrument of data collection," he was subjected to many and various injuries, but he also found that he developed many technical and physical abilities. Sensory ethnography transformed the researcher's body and the way he "sensed" and experienced the world. The "embodied" experiences of the senses enriched the global comprehension of the research object, regarding both the corporeal dispositions of the combatants and the involvement of his five senses in the practice, leading to other forms of socialization and meaningful relations. This approach also provided access to the combatants' interpretation of their bodily pains and injuries, with the acceptability threshold revealing the potential of the body. ${ }^{45}$

Similarly, Kyle Green ${ }^{46}$, like Loïc Wacquant ${ }^{47}$, used his body as a "tool of inquiry and a vector of knowledge." He attested to the "reality" of his study by experiencing the pain arising from the many technical potentialities of MMA. He pointed out that pain attracts the participants for three reasons: (1) trust and being formed by a "real" experience of selfdiscovery; (2) thinking about one's body as a unified but limited organism; (3) and the intimacy between individuals, which builds community.

According to M. Stenius and R. Dziwenka ${ }^{48}$, embodied self-ethnography contributes to a deeper understanding of both MMA and the associated violence. Bodily experiences such as pain make it possible to feel "from within" the emotional and instrumental effects and to better grasp the debate about its brutality. Because of the high level of violence and pain, the authors argue that the practitioners adapt their bodies to a certain barbarity.

From a phenomenological viewpoint, Jacquelyn Allen-Collinson ${ }^{49}$ studied four disciplines including MMA and conceptualized "thermoception" as a distinct sense rather than a specific modality of touch. Thermoception, which is the apprehension of sensations of warmth and coolness, is nearly absent in research and yet it would likely enrich knowledge and the embodied understanding of MMA. According to some authors, the representations related to sweating reflect the levels of engagement and commitment to the

${ }^{43}$ Georges Devereux, De l'Angoisse à la Méthode dans les Sciences du Comportement (Paris: Flammarion, 1980).

${ }^{44}$ Dale C. Spencer, "Sensing violence: An ethnography of mixed martial arts," Ethnography 15 (2014): 232-254.

${ }^{45}$ Dale C. Spencer, "Narratives of despair and loss: pain, injury and masculinity in the sport of mixed martial arts," Qualitative Research in Sport, Exercise and Health 4 (2012): 117-137.

${ }^{46}$ Kyle Green, "It hurts so it is real: sensing the seduction of mixed martial arts," Social \& Cultural Geography 12 (2011): 377-396.

${ }^{47}$ Loï Wacquant, Corps et âme. Carnet ethnographique d'un apprenti boxeur (Marseille: Agone, 2002).

48 Magnus Stenius, Ronald Dziwenka, ""Just Be Natural with Your Body": An Autoethnography of Violence and Pain in Mixed Martial Arts," International Journal of Martial Arts 1 (2015): 1-24.

${ }^{49}$ Jacquelyn Allen-Collinson, Anu Vaittinen, George Jennings, Helen Owton, "Exploring Lived Heat, "Temperature Work," and Embodiment: Novel Auto/Ethnographic Insights from Physical Cultures," Journal of Contemporary Ethnography (2016): 1-23. 
activity. The "embodied" experience and the tuning in to sensible perceptions - especially internal warmth, which can be quite intense - through an enlightened and "sensible" apprehension thus contributes to the development of the practitioner's abilities.

In some countries, MMA has been met with revulsion because of the powerful symbol of the cage - which paradoxically is safer than the ring - as well as the possibility of directing blows to an opponent on the ground and the ultimate goal of incapacitating one's opponent. Although the bibliometric analysis reveals the regulatory, technical and traumarelated diversity and plurality of this total sport practice and its infectious, dietary and physiological dangers, the risks of long-term brain damage is only assumed. To better understand the violence and experience of this controversial discipline, some studies have shown the importance of engaging and experimenting with sensible perceptions such as thermoception or pain. The international bibliography reveals an increased sensitization to the study of MMA in the social sciences, yet evidences the weak presence of sensory ethnographic research. The construction and development of this latter type of study nonetheless represents a renewal in research methodology and points to an opening to "sporting cultural studies."

\section{B. Symbolic violence}

\section{- A Trans-mediatized Object}

No sport today is immune to the transmedia era. Sports have been redefined by the technological networks of new information and obey the dictates of fan culture and logic of storytelling, as described by Henry Jenkins. ${ }^{50}$ We can therefore observe the insertion of bodily dimensions into video games ${ }^{51}$, as well as the sportivization and professionalization of these games, marking their integration into the sports world. ${ }^{52}$ In parallel, the influence of the latest technologies and media on the progression of skills among action-sports practitioners $^{53}$ also attests to the insertion and reconstruction of the digital world into this space, as with the "virtualization" of sporting practices. ${ }^{54}$ Following the global parasportivisation dynamics of $\mathrm{MMA}^{55}$ with its private operators, competitive video games have nevertheless tended to remain free from the modern institutionalized sports system. ${ }^{56} \mathrm{Just}$ as for MMA, these games are conducted within a competitive system of partnerships between associations, private companies and publishers, detached from institutional constraints.

Similar to the intersections between sport and visual culture through developments in digital technologies, MMA has also experienced the cross-use of mediatized tools and visual aids with the dynamics of learning and coaching. Anu Vaittinen ${ }^{57}$ recontextualized Greg

\footnotetext{
${ }^{50}$ Henry Jenkins, Convergence culture: where old and new media collide (New York: New York University Press: 2006).

51 Timothy Crick, "The Game Body: Toward a Phenomenology of Contemporary Video Gaming," Games and Culture 6 (2010): 259-269.

52 Nicolas Besombes, "Les jeux vidéo compétitifs au prisme des jeux sportifs : du sport au sport électronique,” Sciences du Jeu 5 (2016): 1-20.

53 Holly Thorpe, "Action Sports, Social Media, and New Technologies: Towards a Research Agenda," Communication \& Sport 5 (2016): 554-578.

54 Alain Loret, "L'intégration par le sport au risque de l'innovation sportive," Empan 51 (2003): 39-47.

55 Maarten van Bottenburg, Johan Heilbron, "Genèse et Dynamique des "combats ultimes"' : $32-45$.

56 Nicolas Besombes, "Les jeux vidéo compétitifs au prisme des jeux sportifs : du sport au sport électronique": 1-20.

57 Anu Vaittinen, "Intersections: ways of knowing mixed martial arts and visual culture," Amodern 3 (2014): 1-31.
} 
Downey's pioneering contributions ${ }^{58}$ in order to explore MMA in connection with the new economy technologies and noted practitioners' and coaches' commitment to learning via multiple visual tools (smartphones, internet, television, technical manuals, etc.) as key elements for understanding MMA. In this reorganization, the teacher's skills are replaced by an "informational and educational competition" that favours the switch from a pedagogical approach wherein "requirements must be met" to a less hierarchical "autonomous" model wherein participation, initiative and exchanges with students take precedence..$^{59}$

MMA is deeply linked to symbolic representations. Whereas a strategy of "the ultimate," touting ferocity and cruelty, was at the origin of MMA's marketing promotion ${ }^{60}$, the current construction of Nike's or TapOut's advertising campaigns make use of its freedom from regulation and analogies to nature, primitiveness or savagery. Yet this "naturalizing imagery" reinforces the habitus of violence. ${ }^{61} \mathrm{MMA}$ is in some respects a theatre of violence and athletic performance ${ }^{62}$, and Daniele Bolelli63 (2014) resituated the words of Dana White, current president of the UFC, thusly: "We owe big to gladiator and martial arts movies. Movies and video games paved the way for us. All we did was to bring fiction into reality" noting the reciprocal influences of MMA and cinematographic representations of martial arts and the ancient gladiators. Stimulated by the UFC spectacle, its power in the media, and some of its great figures like Ronda Rousey ${ }^{64}$ or Conor McGregor ${ }^{65}$, MMA is helping to construct a mythology that goes beyond the simple framework of its practice and may serve as the foundation for identity constructions (Scott 2016). ${ }^{66}$

\section{- Boundaries in sports}

In the absence of a legal framework and real structure in France, MMA is developing today outside of state control, in contrast to modern sport and the process of the centralization of violence through the monopoly of the state. ${ }^{67}$ In addition, the lack of an approved federation, supervision and specific training does little to ensure the physical or psychological safety of its practitioners. With this in mind, M. Chapitaux ${ }^{68}$ notes the link between various clubs for combat sports like MMA, which are overrepresented in so-called "sensitive" neighbourhoods, and, as well in recruiting grounds for Islamic radicalization.

\footnotetext{
58 Greg Downey. "The Information Economy in No-Holds-Barred Fighting," in Frontiers of Capital: Ethnographic Reflections on the New Economy, ed. Melissa S. Fisher, Greg Downey (Durham: Duke University Press, 2006), 108-132.

59 Matthieu Quidu, "Quelle place pour l'enseignant en Education Physique et Sportive à l'heure des tutoriels sur youtube et des applications pour smartphones ?," 7ème Biennale de l'AFRAPS (2016): 1-13.

${ }^{60}$ Maarten van Bottenburg, Johan Heilbron, "Genèse et Dynamique des "combats ultimes"'” : 32-45.

${ }^{61}$ Matthew P. Ferrari, "Sporting Nature(s): Wildness, the Primitive, and Naturalizing Imagery in MMA and Sports Advertisements," Environmental Communication 7 (2013): 277-296.

62 Magnus Stenius, "Actors of Violence: Staging the Arena in Mixed Martial Arts," Nordic Theatre Studies 23 (2011): 86-97.

${ }^{63}$ Daniele Bolelli, "How Gladiatorial Movies and Martial Arts Cinema Influenced the Development of The Ultimate Fighting Championship," Journalism, Media and Cultural Studies 5 (2014): 1-15.

${ }^{64}$ Riley Chisholm, Charlene Weaving, Kathy Bishoping, "Girl Power Figures, Mythic Amazons, and Neoliberal Risk Performers: Discursively Situating Women Who Participate in Mixed Martial Arts," in Women in Action Sport Cultures, ed. Holly Thorpe, Rebecca Olive (London: Palgrave Macmillan, 2016), 279-298.

65 Darren Kesley, "Affective mythology and 'The Notorious' Conor McGregor: monomyth, mysticism, and mixed martial arts," Martial Arts Studies 5 (2018): 15-35.

${ }^{66}$ D. Travers Scott, "Participation, Pain, and World Making: Affective Political Economies of Irish

Traveller Fight Videos," Television \& New Media 17 (2016): 595-611.

${ }^{67}$ Norbert Elias, La dynamique de l'Occident (Paris: Calmann-Lévy, 1975).

${ }^{68}$ Médéric Chapitaux, Le sport, une faille dans la sécurité de l'Etat (Paris: Enrick B. Editions, 2016).
} 
According to the author, these sometimes unstructured and uncontrolled clubs may serve as a gateway to Jihad training through religious autarky and the "sports educator-recruiter". Nevertheless, if MMA were integrated into a competitive system, a centralizing French federal framework would probably still be challenged by the defenders of its "authentic" model, and these defenders would no doubt see the risk of denaturing and pauperizing it through the appropriations of oligarchies. ${ }^{69}$

On a global scale, publications in the policy and legal sciences have revealed a lack of organizational will and international governance which, in addition to hindering the development of "full contact martial arts" disciplines, confront them with ethical, medical and organizational questions. ${ }^{70}$ Although the application of unified rules has helped to strengthen the safety and health of MMA practitioners, its ban has resulted in the renunciation of an activity with high economic potential in several countries ${ }^{71}$ where the UFC nevertheless displays its dominance over other leagues and its athletes. ${ }^{72}$ Questions about the organization and development of competitions for minors, free from rules or laws, or about the destructive potential of a discipline that can increase the capacity to kill undisciplined individuals ${ }^{73}$ also points to the serious concerns inherent to the regulation and growth of this type of sport.

\section{- Disrupting the dogmas of modern sport}

Some research seems to suggest that the development of these forms of "ultimate fighting" 74 would upset the dogma of male domination in a context where female sports practice is regularly relegated to the background. According to J. McKay and S. Laberge, ${ }^{75}$ modern sport is deeply linked to men and masculinity, which still embody today the symbol of "hegemonic masculinity." 76 According to these authors, this model affects many dimensions of the sports world, such as media coverage, merchandising, consumer culture, sports organizations, body image and violence. Although according to R. Chisholm, C. Weaving and $\mathrm{K}$. Bishoping ${ }^{77}$, the development of female MMA fighting does not fundamentally question gender norms, it does allow women to integrate sports activities that are largely "owned and operated" by men by neutralizing gender effects with the emergence of "girl power," analogies to Amazons, and the celebration of individual merit, risk management, and moral fiber. MMA fuels the sexist ideals of consumerism and

${ }^{69}$ Matthieu Delalandre, Cécile Collinet, "Le mixed martial arts et les ambigüités de sa sportification en France": 293-316.

70 Jikkemien Vertonghen, Marc Theeboom, Els Dom, Veerle De Bosscher, Reinhard Haudenhuyse, "The Organization and Regulation of Full Contact Martial Arts: A Case Study of Flanders," Societies 4 (2014): 654-671.

${ }^{71}$ J. T Smith, "Fighting for Regulation: Mixed Martial Arts Legislation in the United States," Drake Law Review 58 (2010): 617-655.

${ }^{72}$ Hunter Sundberg, "The Justice of Unequal Pay in the UFC: An In-Depth Analysis of the Fighters' Antitrust Class Action Lawsuit Against the UFC and the Misplaced Support of the Proposed Muhammad Ali Expansion Act," Pace Intellectual Property, Sports \& Entertainment Law Forum 8 (2017): 128.

73 Kunen, Stephen, "Superhuman in the Octagon, Imperfect in the Courtroom: Assessing the Culpability of Martial Artists Who Kill During Street Fights," Emory Law Journal 60 (2011): 1389-1435.

74 Maarten van Bottenburg, Johan Heilbron, "Genèse et Dynamique des "combats ultimes"'” : 32-45.

75 Jim McKay, Suzanne Laberge, "Sport et masculinités," Clio. Histoire, femmes et sociétés 23 (2006): 239267.

76 Robert William Connell, Masculinities (Cambridge: Polity Press, 1995).

77 Riley Chisholm, Charlene Weaving, Kathy Bishoping, "Girl Power Figures, Mythic Amazons, and Neoliberal Risk Performers: Discursively Situating Women Who Participate in Mixed Martial Arts," in Women in Action Sport Cultures, 279-298. 
beauty ${ }^{78}$ and suggests the gender inequalities in the construction of marketing strategies. ${ }^{79}$ However, although it makes it possible to structure a "transgressive sexist" duality linked to the image of a "glamazon" representing the heterosexuality and femininity of an imposing body, it also reveals an emancipatory potential among female combatants. Some, like Ronda Rousey, use it to their benefit. ${ }^{80} \mathrm{H}$. Jakubowska, A. Channon and C. R. Matthews ${ }^{81}$ offer an interesting look at the reception of an athlete from a sport with a strong masculine connotation via the MMA champion Joanna Jędrzejczyk. Unlike previous studies, this study is distinguished by a non-sexualized representation associated with a process of "degenrefication" as a full-fledged woman, a legitimate and talented fighter, and national pride. By transferring an "appearance body" to a "performance body" that it legitimizes 82 , women's MMA (WMMA) reveals the potential for empowerment and challenge to male domination, as opposed to the general assumption of the passivity and weakness of women. ${ }^{83}$ In a special issue devoted to the paradoxical corporal commitments related to MMA, coordinated by Matthieu Quidu, A. Channon, A. Quinney, and A. \& C.R. Matthews ${ }^{84}$ reinforced this idea of a sport with the potential to empower. Nevertheless, the authors see the inherent risk of objectifying and reifying female practitioners through marketing and hyper-sexualization and argue that this should be taken into account to promote these women as athletes and, more broadly, to promote the development of WMMA.

At the crossroads of debates and economic, ethical, political, medical and social issues, MMA reveals its marginal and transgressive character. Evolving from the reciprocal influences with digital technologies and video games, this object of transmedia has been constructed and sportivized via multiple media associated with violence. By its spectacularization and over-mediatization, MMA with its "ultimate" nature, the most realistic and successful form of sports opposition, reflects a certain "exceptionalism" 85 in the sports field. It implies a subversive potential transcending the normative sexist discourses on gender. ${ }^{86}$ In addition, the presence and exposure of non-white athletes in disciplines like MMA help neutralize hegemonic masculinity. This sport could therefore

\footnotetext{
${ }^{78}$ Charlene Weaving, "Cage fighting like a girl: exploring gender constructions in the ultimate fighting championship (UFC)," Journal of the Philosophy of Sport 41 (2014): 129-142.

${ }^{79}$ Minyong Lee, Kalik Nesbitt, Alexander Brothers, Tiffany Fuller,"Female Fighters in MMA, Fight Like a Girl: A Look into Female Fighters from a Marketing Approach," International Journal of Business and Social Science 8 (2017): 16-21.

80 Pam R. Sailors, Charlene Weaving, "Foucault and the Glamazon: The Autonomy of Ronda Rousey," Sport, Ethics and Philosophy 11 (2017): 428-439.

81 Honorata Jakubowska, Alex Channon, Christopher R. Matthews, "Gender, Media, and Mixed Martial Arts in Poland: The Case of Joanna Jędrzejczyk," Journal of Sport and Social Issues 40 (2016): 410431.

82 Trisha Kemerly, Tony Kemerly, "Caught in the Panopticon: Gender Performativity in Women's Mixed Martial Arts." Popular Culture Association \& American Culture Association National Conference (New Orleans, March 2015).

83 Mark Mierzwinski, Philippa Velija, Dominic Malcolm, "Women's Experiences in the Mixed Martial Arts: A Quest for Excitement?," Sociology of Sport Journal 31 (2014): 66-84.

84 Alex Channon, Ally Quinney, Anastasiya Khomutova, Christopher R. Matthews, "Sexualisation of the fighter's body: some reflections on women's mixed martial arts,” Corps 16 (2018): 383-391.

85 Honorata Jakubowska, Alex Channon, Christopher R. Matthews, "Gender, Media, and Mixed Martial Arts in Poland: The Case of Joanna Jędrzejczyk": 410-431.

86 Alex Channon, Alex, Christopher R Matthews, "Approaching the Gendered Phenomenon of "Women Warriors'," in Global Perspectives on Women in Combat Sports: women around the world, ed. Alex Channon, Christopher R. Matthews (Basingstoke: Palgrave Macmillan, 2015), 1-21.
} 
"provide minority men with the opportunity to disavow the legacy of imperialism and colonialism that has relegated them to the status of 'other'." 87

\section{The play impulse \\ - Hybridization of the fight}

As a hybrid activity, MMA brings together and combines fighting techniques from various sources, such as Muay Thai, wrestling and Brazilian jiu jitsu. Due to its technical complementarity and physiological demands, it requires a well-planned and carefully adapted training program to improve athletic performance and reduce the risk of muscle pain and injury. 88

History nevertheless reveals multiple and earlier trends towards hybridization, especially among ancient Chinese warriors. In their image, the discipline "jeet kune do" was founded by Bruce Lee who popularized it cinematographically. This influenced the creation of MMA and revealed the interest of realistic fighting by combining techniques from different disciplines. ${ }^{89}$ Although the first tournaments of Vale Tudo showed the domination of Brazilian jiu jitsu, MMA moved away from its ceremonial character in favour of warlike values and efficiency, more representative of professional sport and commercial internationalization..$^{90}$ This willingness to mix is also observable in combat training centres, such as the "Warrior Muay Thai" (WMT) in Thailand. Many culturally diverse practices are taught there, such as Muay Thai, Brazilian jiu jitsu, Greco-Roman wrestling and even MMA. This camp provides trainees with a "liminal" space that fosters individual, embodied, sensory and intercultural training. According to Solomon Lennox ${ }^{91}$, the WMT promotes the development of an "idiosyncratic training regime" tailored to the needs and personal goals of the combatants, the vast majority of whom are non-professionals pursuing their own projects, including "ontological transcendence."

Although the organization of inter-style confrontations led to the involuntary construction of a hybrid combat discipline, the professional form of MMA is today affected by a double paradoxical movement of technical narrowing and standardization, resulting from economic, media and regulatory challenges promoting performance, efficiency and the spectacular dimension of combat. ${ }^{92}$ Nevertheless, the normalization of fighting has seemed to impoverish the gestures, while masking the multiple educational, tactical and strategic compensations that represent its richness and creative and innovative potential due to its hybrid structure and regulatory freedom. This technical creativity is therefore essential for professional fighters seeking to provoke uncertainty and defeat their opponents. ${ }^{93}$

\footnotetext{
${ }^{87}$ Jim McKay, Suzanne Laberge, "Sport et masculinités." Authors' translation.

${ }^{88}$ Pablo B. Costa, Hugo Medeiros, David H. Fukuda,"Warm-up, Stretching, and Cool-down Strategies for Combat Sports," Strength \& Conditioning Journal 33 (2011): 71-79.

${ }^{89}$ William Acevedo, Mey Cheung. "Una visión histórica de las artes marciales mixtas en China," Revista de Artes Marciales Asiáticas 6 (2011): 29-44.

${ }^{90}$ Franck Poupeau, ""Vale todo" en Bolivie. Note de recherche sur l'internationalisation du jujitsu brésilien," Actes de la recherche en sciences sociales 179 (2009): 46-51.

${ }^{11}$ Solomon Lennox, "Liminal spaces and experimental practices in the Warrior Muay Thai training camp," Theatre, Dance and Performance Training 7 (2016): 494-497.

${ }_{92}$ Matthieu Quidu, "Le Mixed Martial Arts entre innovation et hybridation : genèse et développement techniques d'un sport de combat de synthèse," Sciences sociales et sport (2017).

${ }^{3}$ Matthieu Quidu, "Quelle créativité corporelle en MMA ? Entre uniformisation gestuelle et compensations techniques," Corps 16 (2018): 403-415.
} 


\section{- A Sports Indiscipline}

Jean-Paul Clément's study ${ }^{94}$ offers an original analysis of the relationship between guard distance, the conception of confrontation, and violence by comparing three disciplines of grappling combat (wrestling, judo and aikido). He notes that the violence decreases as the guard distance increases. In terms of motor skills, the body's engagement is different in judo and aikido, whose internal logic is based on the grip (kumi-kata) for the judoka and the wrists for the aikidoka.

In addition to its "reverse sportivization," 95 where the competitive aspect is historically ahead of the game and leisure aspects, MMA is distinguished by its ultimate guard distance. By using small, open gloves that protect the hand while providing finger mobility, the fighter mobilizes the fighters entire body and can hit, grab and dominate the opponent at any distance, from the farthest to the closest. If the fight starts in the standing position, like Muay Thai, the "mixed martial artist" can dominate his opponent in hand-to-hand combat, control him, bring him to the ground and then keep hitting him in a phase called "ground and pound," which can lead to such close contact that the sweat and even the blood of the two opponents mixes. The plural nature of this guard distance thus marks a break with the modern logic that weakens the games in order to discipline them.

\section{- Towards Legitimate Practice}

MMA and combat video games represent a certain deviance, violence and/or deregulation. ${ }^{96}$ MMA practitioners, like video gamers, want legitimacy for their sport and the end of social stigmatization..$^{97}$ MMA has been taken up in various educational circles to encourage its sportivization. M. Quidu and M. Delalandre ${ }^{98}$ conducted a study with students from the ENS de Lyon and demonstrated the playful and educational potentialities of this discipline despite its ban in France. The student-practitioners seemed to value the efficiency, the diversified mobilization of energy and muscular zones, and the technical and strategic possibilities that characterize this discipline. According to the authors, MMA taught in a safe and protective environment can contribute to student well-being in various ways: easing tensions; developing skills of physical and mental qualities; and promoting selfdetermination and relational well-being.

The practice of MMA can be more than a simple outlet, offering the possibility of life betterment, according to various student profiles. In this sense, it can contribute to the transfer and development of multiple life skills in non-sporting contexts for young people, including: self-defence, self-confidence, self-control and social skills, although these would need to be part of a strategy of adapted training, structured by the coach, athlete and parent relationship. ${ }^{99}$

\footnotetext{
${ }^{94}$ Jean-Paul Clément, "Etude comparative de trois disciplines de combat (lutte, judo, aïki-do) et de leurs usages sociaux," Ph.D thesis (University of Paris Diderot, 1985).

${ }^{95}$ Yann Ramirez, "Du Free Fight aux Arts Martiaux Mixtes : sportivisation, violence et réception d'un sport de combat extrême," Ph.D thesis (University of Montpellier, 2015).

96 Thierry Blin, "Tous les coups sont permis. Sur les nouveaux gladiateurs du free fight." Le débat 176 (2013): 159-170.

${ }^{97}$ Nicolas Besombes, "Les jeux vidéo compétitifs au prisme des jeux sportifs : du sport au sport électronique": 1-20.

98 Matthieu Quidu, Matthieu Delalandre, "Être Normaliens et pratiquants de Mixed Martial Arts," SociologieS (2018), http://journals.openedition.org/sociologies/6609 (accessed April 19, 2018).

${ }^{99}$ Theresa M. Beesley, "Grappling For Answers: Exploring the Process of Life Skills Development in Youth Mixed Martial Arts Athletes," Doctoral dissertation (University of Toronto, 2016).
} 
Along these lines, several articles have suggested the practice of MMA for therapeutic purposes. J. McKeehan ${ }^{100}$ studied the impact of a training program adapted for children on the autism spectrum and noted significant changes to the maintenance of social skills, physical abilities, respect and general attitude. "Integra Mindfulness Martial Arts," a group therapy program that combines mindfulness meditation and cognitive-behavioural therapy, also showed improved academic outcomes, social relationships, self-confidence, and emotional management in high school students with regulation difficulties and at risk of chronic stress. ${ }^{101}$ In addition, "Integra MMA" showed a positive impact on the social behaviours and relationships of adolescents with learning disabilities, attention deficit hyperactivity disorder (ADHD) and anxiety. ${ }^{102}$ These finding suggest an alternative to traditional behavioural therapies.

MMA differs from traditional combat disciplines in its physical, technical and tactical complementarity. In favour of efficiency, it dispenses with the ritualized character of some martial arts and offers practitioners the freedom to build their own fighting style. Its hybrid structure, regulatory freedom, and variation in guard distance offers practitioners the possibility of bodily commitment and violence, with a wealth of options inspiring innovation and creativity, all culminating in a kind of "creative violence." Paradoxically criticized for its "ultimate" nature, MMA, with its technical, physiological and mental components reveals playful, pedagogical, educational and therapeutic potentialities, concentrating on multiple issues stimulated by an illegal/illegitimate duality, which has disturbed its process of sportivization.

\section{Conclusion}

This bibliometric analysis shows the heightened level of physical violence in MMA, although forms that are more playful or therapeutic seem to indicate a deeper integration of self-restraint, thus contributing to the civilizing process. However, according to N. Elias and E. Dunning, this process should lead to a lower threshold of tolerance for individual violence. Therefore, should we understand the growth of MMA as a sign of the decivilization process at work? What elements make this clear? Contrary to André Rauch's ${ }^{103}$ demonstration that consent to physical injury in boxing declines as society becomes more civilized, MMA seems to reflect the increasing acceptability of violence and even its showcasing. According to F. Delmotte, ${ }^{104}$ three indicators suggest the validity of the thesis of a decivilizing process.

The first is based on the observation of an institutional weakening of modern sport. Indeed, three quarters of current athletes practise outside institutions, which calls into question the monopolistic purpose - in the sense of Elias ${ }^{105}$ - of modern sport to define the

\footnotetext{
${ }^{100}$ James McKeehan, "The arts of martial behavior: using martial arts as a behavioral intervention for children with autistic spectrum disorders," Master thesis (University of Kaplan, 2012).

${ }^{101}$ K. Milligan, R. Cosme, M.W. Miscio, L. Mintz, L. Hamilton, M. Cox, S. Woon, M. Gage, M. Phillips, "Integrating Mindfulness into Mixed Martial Arts Training to Enhance Academic, Social, and Emotional Outcomes for At-Risk High School Students: a Qualitative Exploration," Contemporary School Psychology 21 (2017): 335-346.

102Jillian Haydicky, Judith Wiener, Paul Badali, Karen Milligan, Joseph M. Ducharme, "Evaluation of a Mindfulness-based Intervention for Adolescents with Learning Disabilities and Co-occurring ADHD and Anxiety," Mindfulness 3 (2012): 151-164.

103 André Rauch, "Violence et maitrise de soi en boxe," Communications 56 (1993): 139-154.

${ }^{104}$ Florence Delmotte, "Une théorie de la civilisation face à " l'effondrement de la civilisation "." \& "Termes clés de la sociologie de Norbert Elias."

105 See Norbert Elias, La dynamique de l'Occident; Norbert Elias, La société des individus (Paris: Fayard, 1991).
} 
norms of violence and their incorporation by playful practices. Thus, learning to control the play impulse does not pass mainly, or more weakly, by the "Selbstzwang" (self-control) 106 proposed by institutionalized sports practice.

The second indicator concerns the transformations of modern sport in the twentieth century. Among other factors, the massive spread of sport, as reflected by the increase in the number of club members and competitions, and the diversification of practices, has resulted in logics of rationalization and bureaucratization that are peculiar to this period, which is in agreement with Elias's configurational postulate. This has resulted in an increase in regulatory constraints that have not turned into self-restraint, but instead have given rise to disaffection and a shift towards bodily leisure practices with minimal rules. The emergence of gliding and board sports noted by Loret ${ }^{107}$ and the findings of disaffiliation at the end of the twentieth century are indicators, as are the emergence and development of MMA noted in this article.

The third sign of a decivilizing process is expressed, according to Delmotte, by the transformation in bodily control, or what we think of as the transformation in the relation to the body and the integration of control. Two directions attest to the relevance of this indicator for MMA. The first is based on sports trauma studies. These studies show the overabundance of corporeal "sacrality" built by the civilizing process of modern sport, whether in the logics of engagement, with injury as the symptom ${ }^{108}$, in the valorisation of risky behaviours, ${ }^{109}$ or the stress response that increases the possibility of accidents. ${ }^{110}$ Although debatable, given the political and sports issues at stake, the words of certain sports actors like Jean-Luc Rougé, president of the French Judo Federation, reveal the underlying assumption of this transformation in the relation to the body. For example, Jean-Luc Rougé compares the physical integrity produced by regulation and the video-playful violence of MMA. He also suggests the second direction revealing a transformation in the relation to the body: the shift from control of the play impulse in the sports space towards media virtuality. In fact, the powerful presence of the media and digital leisure in today's society is such that they disseminate the norms of self-regulation that lead to a derealization of corporealities. As Pierre Fabre ${ }^{111}$ points out, the contradictory nature of contemporary Western societies tends to delegitimize and stigmatize violence, but its representations are also increasingly accepted and displayed as a spectacle in certain media. We see this as the expression of a physical violence that is embodied in the multiple digital identities and avatars of video games.

The forms of the institutionalization of MMA (circuits of professional competitions, formalization and organization of amateur encounters, legally acceptable forms of fighting like pankration) suggest the hypothesis of an "over-civilization" at work in the development of UFC - in other words, a deeper stage in the civilizing process by the increased selfrestraint in these practices. But the three identified indicators - institutional weakening,

\footnotetext{
106 Norbert Elias, La civilisation des maurs.

107 Alain Loret, "L'intégration par le sport au risque de l'innovation sportive" : 39-47.

${ }^{108}$ Luiggi \& Griffet, "La blessure comme indicateur de l'engagement sportif," in L'engagement sportif an prisme des sciences sociales, ed. Gilles Ferréol (Louvain-la-Neuve: EME Editions, 2016), 101-113.

109 Cécile Martha, Jason Laurendeau, Jean Griffet, "Comparative optimism and risky road traffic behaviors among high-risk sports practitioners," Journal of Risk Research 13 (2010): 429-444.

110 Thomas Deroche, Yannick Stephan, G. Lecocq, Christine Le Scanff, "Les déterminants psychologiques de la blessure physique du sportif : Une revue de question," Psychologie Francaise 52 (2007): 389-402.

111 Pierre Fabre, "Quand la police fabrique l'ordre social," Revue française de science politique 59 (2009): 1231-1248.
} 
rationalization/bureaucratization, and the transformation of the relationship to the body confirm a decivilizing phase in the oscillations of the civilizing process. More broadly, is it possible that we are witnessing the expression of a foundational violence that is quietly and beneath the surface creating a new sporting theme?

\section{References}

Abramson, Corey M., Darren Modzelewski. "Caged Morality: Moral Worlds, Subculture, and Stratification Among Middle-Class Cage-Fighters." Qualitative Sociology 34 (2011): 143-175.

Acevedo, William, Mey Cheung. "Una visión histórica de las artes marciales mixtas en China." Revista de Artes Marciales Asiáticas 6 (2011): 29-44.

Allen-Collinson, Jacquelyn, Anu Vaittinen, George Jennings, Helen Owton. "Exploring Lived Heat, 'Temperature Work,' and Embodiment: Novel Auto/Ethnographic Insights from Physical Cultures." Journal of Contemporary Ethnography (2016): 1-23.

Anheim, Etienne, Benoît Grévin. «Le procès du "procès de civilisation" ? Nudité et pudeur selon H. P. Duerr. » Revue d'bistoire moderne \& contemporaine 48 (2001) : 160-181.

Baker, Joseph F., Brian M.Devitt, Ray Moran. "Anterior cruciate ligament rupture secondary to a 'heel hook': a dangerous martial arts technique." Knee Surgery, Sports Traumatology, Artbroscopy 18 (2010): 115-116.

Barthes, Roland. Mythologies. Paris: Seuil, 1957.

Bastidas, Nicholas, Jamie P. Levine, Frank L. Stile. "The 'sweet science' of reducing periorbital lacerations in mixed martial arts." Annals of Plastic Surgery 68 (2012): 43-45.

Beesley, Theresa M. "Grappling For Answers: Exploring the Process of Life Skills Development in Youth Mixed Martial Arts Athletes." Doctoral dissertation, University of Toronto, 2016.

Besombes, Nicolas. «Les jeux vidéo compétitifs au prisme des jeux sportifs : du sport au sport électronique. » Sciences du Jeu 5 (2016) : 1-20.

Bishop, Stacey Howard, Paul La Bounty, Michael Devlin. "Mixed martial arts: a comprehensive review." Journal of Sport and Human Performance 1 (2013): 28-42.

Blin, Thierry. "Tous les coups sont permis. Sur les nouveaux gladiateurs du free fight." Le débat 176 (2013) : 159-170.

Bolelli, Daniele. "How Gladiatorial Movies and Martial Arts Cinema Influenced the Development of The Ultimate Fighting Championship." Journalism, Media and Cultural Studies 5 (2014): 1-15.

Bottenburg, Maarten van, Johan Heilbron. "Genèse et Dynamique des "combats ultimes"." Actes de la Recherche en Sciences Sociales 179 (2009) : 32-45.

Bush, S. S., T. Myers. "Concussive brain injury in mixed martial arts: Fighter characteristics and bout outcomes." Applied Neuropsychology 16 (2009): 298.

Channon, Alex, Christopher R. Matthews. "Approaching the Gendered Phenomenon of 'Women Warriors'." In Global Perspectives on Women in Combat Sports: women around the world, ed. Alex Channon, Christopher R. Matthews, 1-21. Global culture and sport series. Basingstoke: Palgrave Macmillan, 2015.

Channon, Alex, Ally Quinney, Anastasiya Khomutova, Christopher R. Matthews. "Sexualisation of the fighter's body: some reflections on women's mixed martial arts." Corps 16 (2018): 383-391.

Chapitaux, Médéric. Le sport, une faille dans la sécurité de l'Etat. Paris : Enrick B. Editions, 2016.

Chisholm, Riley, Charlene Weaving, Kathy Bishoping. "Girl Power Figures, Mythic Amazons, and Neoliberal Risk Performers: Discursively Situating Women Who 
Participate in Mixed Martial Arts." In Women in Action Sport Cultures, ed. Holly Thorpe, Rebecca Olive, 279-298. London : Palgrave Macmillan, 2016.

Clément, Jean-Paul. «Etude comparative de trois disciplines de combat (lutte, judo, aïki-do) et de leurs usages sociaux.» Ph.D thesis, University of Paris Diderot, 1985.

Collins, Randall. Interaction Ritual Chains. Princeton: Princeton University Press, 2004.

Connell, Robert William. Masculinities. Cambridge: Polity Press, 1995.

Costa, Pablo B., Hugo Medeiros, David H. Fukuda. "Warm-up, Stretching, and Cool-down Strategies for Combat Sports.” Strength \& Conditioning Journal 33 (2011): 71-79.

Crick, Timothy. "The Game Body: Toward a Phenomenology of Contemporary Video Gaming." Games and Culture 6 (2010): 259-269.

Delalandre, Matthieu, Cécile Collinet. «Le mixed martial arts et les ambigüités de sa sportification en France. » Loisir et société 35 (2012) : 293-316.

Delmotte, Florence. «Termes clés de la sociologie de Norbert Elias ». Vingtième Siècle. Revue d'bistoire 106 (2010) : 29-36.

. "Une théorie de la civilisation face à "l'effondrement de la civilisation". » Vingtième Siècle. Revue d'bistoire 106 (2010) : 54-70.

Deroche, Thomas, Stephan, Yannick, Lecocq, G., Le Scanff, Christine. «Les déterminants psychologiques de la blessure physique du sportif : Une revue de question. » Psychologie Française 52 (2007) : 389-402.

Devereux, Georges. De l'angoisse à la méthode dans les sciences du comportement. Paris : Flammarion, 1980.

Downey, Greg. "The Information Economy in No-Holds-Barred Fighting." In Frontiers of Capital: Ethnographic Reflections on the New Economy, ed. Melissa S. Fisher, Greg Downey, 108-132. Durham : Duke University Press, 2006.

Duerr, Hans Peter. Nudité Et Pudeur : Le Mythe Du Processus De Civilisation. Paris : Maison Des Sciences De L'homme, 1998.

Dunning, Eric. "Approche figurationnelle du sport moderne. Réflexions sur le sport, la violence et la civilisation." Vingtième Siècle. Revue d'histoire 106 (2010) : 177-191.

Elias, Norbert, Dunning, Eric. Sport et civilisation : La violence maitrisée. Paris : Fayard, 1994. La civilisation des mours. Paris : Calmann-Lévy, 1973.

La dynamique de l'Occident. Paris : Calmann-Lévy, 1975.

La société des individus. Paris : Fayard, 1991.

Les Allemands, Luttes et pouvoir et développement de l'babitus aux XIXe et XXe siècles. Paris : Seuil, 2017.

Fabre, Pierre. «Quand la police fabrique l'ordre social. » Revue française de science politique 59 (2009) : 1231-1248.

Ferrari, Matthew P. «Sporting Nature(s): Wildness, the Primitive, and Naturalizing Imagery in MMA and Sports Advertisements. » Environmental Communication 7 (2013): 277-296.

Fields, Jeffrey D., Douglas B. McKeag, John L. Turner. “Traumatic tympanic membrane rupture in a mixed martial arts competition." Current Sports Medicine Reports 7 (2008): 10 11.

Giulianotti, Richard. Sport and Modern Social Theorists. New York: Palgrave Macmillan, 2004.

Granger, Christophe. "Du relâchement des mœurs en régime tempéré. Corps et civilisation dans l'entre-deux-guerres." Vingtième Siècle. Revue d'bistoire 106 (2010) : 115-125.

Green, Kyle. "It hurts so it is real: sensing the seduction of mixed martial arts." Social \& Cultural Geography 12 (2011): 377-396.

Gupta, Nishant, Komal Sharma, Itisha Bansal, Yogesh Kumar, Daichi Hayashi.

"Kickboxing power hour: case report of fifth metatarsal apophysitis (Iselin disease) and its magnetic resonance imaging features.” Translational Pediatrics 6 (2017): 98-101. 
Haut, Jan, Paddy Dolan, Dieter Reicher, Raul Sanchez Garcia. Excitement Processes. Norbert Elias's unpublished works on sport, leisure, body, culture. Wiesbaden: Springer VS, 2018.

Haydicky, Jillian, Judith Wiener, Paul Badali, Karen Milligan, Joseph M. Ducharme. "Evaluation of a Mindfulness-based Intervention for Adolescents with Learning Disabilities and Co-occurring ADHD and Anxiety." Mindfulness 3 (2012): 151-164.

Jakubowska, Honorata, Alex Channon, Christopher R. Matthews. "Gender, Media, and Mixed Martial Arts in Poland: The Case of Joanna Jędrzejczyk." Journal of Sport and Social Issues 40 (2016): 410-431.

Jenkins, Henry. Convergence culture: where old and new media collide. New York: New York University Press: 2006.

Jetton, Adam M., Marcus M. Lawrence, Marco Meucci, Tracie L. Haines, Scott R. Collier, David M. Morris, Alan C. Utter. "Dehydration and acute weight gain in mixed martial arts fighters before competition." The Journal of Strength \& Conditioning Research 27 (2013): 1322-1326.

Kemerly, Trisha, Tony Kemerly. 2015. "Caught in the Panopticon: Gender Performativity in Women's Mixed Martial Arts.” Popular Culture Association \& American Culture Association National Conference, New Orleans, March.

Kesley, Darren. "Affective mythology and 'The Notorious' Conor McGregor: monomyth, mysticism, and mixed martial arts." Martial Arts Studies 5 (2018): 15-35.

Kunen, Stephen. "Superhuman in the Octagon, Imperfect in the Courtroom: Assessing the Culpability of Martial Artists Who Kill During Street Fights." Emory Law Journal 60 (2011): 1389-1435.

Larsen, Jon-Atle. "Kartleggelse av skaderisiko innen kampsporten [Mapping of injury risk in martial arts]." Master dissertation, University of Tromsø, 2013.

Lee, Alexander D., Alexander Yu, Shayne B. Young, Patrick J. Battaglia, John C. Ho. "Omohyoid Muscle Syndrome in a Mixed Martial Arts Athlete: A Case Report." Sports Health: A Multidisciplinary Approach 7 (2015): 458-462.

Lee, Minyong, Kalik, Nesbitt, Alexander Brothers, Tiffany Fuller. "Female Fighters in MMA, Fight Like a Girl: A Look into Female Fighters from a Marketing Approach.” International Journal of Business and Social Science 8 (2017): 16-21.

Lee, Simon K. "Molluscum Contagiosum Infection in Mixed Martial Arts Fighting: Molluscum Gladiatorum.” Journal of Cutaneous Medicine and Surgery 17 (2013): 151-152.

Lennox, Solomon. "Liminal spaces and experimental practices in the Warrior Muay Thai training camp." Theatre, Dance and Performance Training 7 (2016): 494-497.

Linhardt, Dominique. «Le procès fait au Procès de civilisation. A propos d'une récente controverse allemande autour de la théorie du processus de civilisation de Norbert Elias. » Politix 14 (2001) : 151-181.

Loret, Alain. Génération glisse : dans l'eau, l'air, la neige...la révolution du sport des " années fun » Autrement, 1995.

“L'intégration par le sport au risque de l'innovation sportive. » Empan 51 (2003) : 3947.

Loudcher, Jean-François, Monica Aceti. «MMA, "procès” de civilisation et sportivisation : repenser la théorie éliasienne pour mieux s’en émanciper ?» Corps 16 (2018) : 371-381.

Luiggi M., J, Griffet., «La blessure comme indicateur de l'engagement sportif. » In L'engagement sportif au prisme des sciences sociales, ed. Gilles Ferréol, Jean-Paul Callède, 101113. Louvain-la-Neuve : EME Editions, 2016.

Lystad, Reidar P., Gregory, Kobi, Wilson, Juno. “The Epidemiology of Injuries in Mixed Martial Arts. A Systematic Review and Meta-analysis." Orthopaedic Journal of Sports Medicine 2 (2014): 1-10. 
Malcolm, Dominic, Louise Mansfield. "The Quest for Exciting Knowledge: Developments in Figurational Sociological Research on Sport and Leisure." Politica y Sociedad 50 (2013): 397-419.

Malcolm, Dominic. "Sport Medicine, Injured Athletes and Norbert Elias's Sociology of Knowledge." Sociology of Sport Journal 28 (2011): 284-302.

Mansfield, Louise. "Reconsidering feminisms and the work of Norbert Elias for understanding gender, sport and sport-related activities" European Physical Education Review 14 (2008): 93-121.

Martha, Cécile, Jason, Laurendeau, Jean Griffet. «Comparative optimism and risky road traffic behaviors among high-risk sports practitioners. » Journal of Risk Research 13 (2010): 429-444.

McKay, Jim, Suzanne Laberge. "Sport et masculinités." Clio. Histoire, femmes et sociétés 23 (2006) : 239-267.

McKeehan, James. "The arts of martial behavior: using martial arts as a behavioral intervention for children with autistic spectrum disorders" Master thesis, University of Kaplan, 2012.

Mennell, Stephen. "The Contribution of Eric Dunning to the Sociology of Sport: The Foundations." Sport in Society: Cultures, Commerce, Media, Politics 9 (2006): 514-532.

Meulener Marc, Barry L. Smith. "Herpes Gladiatorum With Ocular Involvement in a Mixed Martial Arts Fighter" Cutis 87 (2011): 146-147.

Mierzwinski, Mark, Philippa Velija, Dominic Malcolm. "Women's Experiences in the Mixed Martial Arts: A Quest for Excitement?" Sociology of Sport Journal 31 (2014): 66-84.

Milligan, K., R. Cosme, M.W. Miscio, L. Mintz, L. Hamilton, M. Cox, S. Woon, M. Gage, M. Phillips. "Integrating Mindfulness into Mixed Martial Arts Training to Enhance Academic, Social, and Emotional Outcomes for At-Risk High School Students: a Qualitative Exploration." Contemporary School Psychology 21 (2017): 335-346.

Murray, Joshua, Arnout Van de Rijt, John M. Shandra. "Why They Juice: The Role of Social Forces in Performance Enhancing Drug Use by Professional Athletes. » Sociological Focus 46 (2013): 281-294.

Nalepa, Bryce, Amy Alexander, Sarah Schodrof, Charles Bernick, Jamie Pardini. "Fighting to keep a sport safe: toward a structured and sport-specific return to play protocol." The Physician and Sportsmedicine 45 (2017): 145-150.

Neyra, D. "Fight Kids: The Future of Mixed Martial Arts or a Detriment to America's Youth? A Call to Regulate Children's MMA." Family Court Review 51 (2013): 727-741.

Poupeau, Franck. " "Vale todo" en Bolivie. Note de recherche sur l'internationalisation du jujitsu brésilien. » Actes de la recherche en sciences sociales 179 (2009) : 46-51.

Quidu, Matthieu, Matthieu Delalandre. «Etre Normaliens et pratiquants de Mixed Martial Arts.» SociologieS (2018). http://journals.openedition.org/sociologies/6609 (accessed April 19, 2018).

Quidu, Matthieu. "Quelle place pour l'enseignant en Education Physique et Sportive à l'heure des tutoriels sur youtube et des applications pour smartphones?» Tème Biennale de l'AFRAPS (2016) : 1-13.

"Le Mixed Martial Arts entre innovation et hybridation : genèse et développement techniques d'un sport de combat de synthèse. » Sciences sociales et sport (2017).

"Quelle créativité corporelle en MMA ? Entre uniformisation gestuelle et compensations techniques. » Corps 16 (2018) : 403-415.

Ramirez, Yann. «Du Free Fight aux Arts Martiaux Mixtes : sportivisation, violence et réception d'un sport de combat extrême. » Ph.D thesis, University of Montpellier, 2015.

Rauch, André. «Violence et maîtrise de soi en boxe. » Communications 56 (1993): 139-154. 
Reider, Bruce. "Battle Scars.” The American Journal of Sports Medicine 42 (2014): 1287-1288.

Sailors, Pam R., Charlene Weaving. "Foucault and the Glamazon: The Autonomy of Ronda Rousey." Sport, Ethics and Philosopby 11 (2017): 428-439.

Sánchez, Garcia Raul, Dominic Malcolm. "Decivilizing, civilizing or informalizing? The international development of Mixed Martial Arts." International Review for the Sociology of Sport 45 (2010): 39-58.

Sánchez, Garcia Raul. "Informalization, ways of engagement and class habitus in the development of MMA." Corps 16 (2018): 393-401.

Scott, D. Travers. «Participation, Pain, and World Making: Affective Political Economies of Irish Traveller Fight Videos. » Television \& New Media 17 (2016): 595-611.

Sims, Kevin, Andreo Spina. "Traumatic anterior shoulder dislocation: a case study of nonoperative management in a mixed martial arts athlete." The Journal of the Canadian Chiropractic Association 53 (2009): 261-271.

Smith, J. T. "Fighting for Regulation: Mixed Martial Arts Legislation in the United States." Drake Law Review 58 (2010): 617-655.

Spencer, Dale C. "Narratives of despair and loss: pain, injury and masculinity in the sport of mixed martial arts." Qualitative Research in Sport, Exercise and Health 4 (2012): 117-137.

. "Sensing violence: An ethnography of mixed martial arts." Ethnography 15 (2014): 232-254.

Stenius, Magnus, Ronald Dziwenka. “"Just Be Natural with Your Body”: An Autoethnography of Violence and Pain in Mixed Martial Arts." International Journal of Martial Arts 1 (2015): 1-24.

Stenius, Magnus. “Actors of Violence: Staging the Arena in Mixed Martial Arts.” Nordic Theatre Studies 23 (2011): 86-97.

Sundberg, Hunter. "The Justice of Unequal Pay in the UFC: An In-Depth Analysis of the Fighters' Antitrust Class Action Lawsuit Against the UFC and the Misplaced Support of the Proposed Muhammad Ali Expansion Act.” Pace Intellectual Property, Sports \& Entertainment Law Forum 8 (2017): 1-28.

Thorpe, Holly. “Action Sports, Social Media, and New Technologies: Towards a Research Agenda." Communication \& Sport 5 (2016): 554-578.

Vaittinen, Anu. "Intersections: ways of knowing mixed martial arts and visual culture." Amodern 3 (2014): 1-31.

Van Bottenburg, M., J. Heilbron. "Dans la cage. Genèse et dynamique des "combats ultimes"." Actes de la recherche en sciences sociales 179 (2009) : 32-45.

. "Informalization or de-sportization of fighting contests? A rejoinder to Raúl Sánchez García and Dominic Malcolm." International Review for the Sociology of Sport 46 (2010): 125-127.

Vertonghen, Jikkemien, Marc Theeboom, Els Dom, Veerle De Bosscher, Reinhard Haudenhuyse. "The Organization and Regulation of Full Contact Martial Arts: A Case Study of Flanders." Societies 4 (2014): 654-671.

Wacquant, Loïc. Corps et âme. Carnet ethnographique d'un apprenti boxeur. Marseille: Agone, 2002.

Weaving, Charlene. "Cage fighting like a girl: exploring gender constructions in the ultimate fighting championship (UFC)." Journal of the Philosophy of Sport 41 (2014): 129-142.

Weber, Max. Economie et societé. Paris : Plon, 1971.

Wouters, Cas. Informalisierung. Norbert Elias' Zivilisationstheorie und Zivilisationsprozesse im 20. Jahrbundert. Opladen: Westdeutscher Verlag, 1999.

Wouters, Cas. «Comment les processus de civilisation se sont-ils prolongés ? De la “seconde nature" à la "troisième nature". » Vingtième Siècle. Revue d'bistoire 106 (2010) : 161-175. 